JULIE MARCUS

\section{ruptured reconciliation}

\begin{tabular}{l} 
JON ALTMAN AND MELINDA HINKSON (EDS) \\
\hline $\begin{array}{l}\text { Coercive Reconciliation: Stabilise, Normalise, } \\
\text { Exit Aboriginal Australia }\end{array}$ \\
\hline Arena Publications, Melbourne, 2007 \\
\hline ISBN 9780980415803 \\
\hline RRP $\$ 27.50$
\end{tabular}

The Howard government's radical and decisive 'emergency intervention' in the Aboriginal lands of the Northern Territory in 2007 took almost everyone by surprise; for many, it was the final step in implementing a long-held government agenda aimed at re-establishing control over Aboriginal lands. The title of one of the essays in the collection under review, Patrick Dodson's 'Whatever Happened to Reconciliation', captures that initial moment, the shock at how the ground had shifted and the consequent need for a restatement of the principles for progressive development that the intervention had so suddenly shunted aside. To say that the intervention caught most people off guard would be an understatement.

Equally astonishing was the use of the army to move across the Northern Territory in a wave of shock and awe, rolling out the first phase of the government's programs. The militarised shape of the intervention was important at the time partly as a warning that, this time, the government would not be deterred by the sort of opposition they faced over the Reeves Report into the land rights legislation, but also because by using the army the government was able to put boots on the ground in a way that circumvented any existing labour force-just as in an earlier confrontation they had relied on an externally trained alternative workforce to break with the unionised wharfies. In this context the use of the army to move in and take control makes a certain amount of sense, regardless of whether Aboriginal soldiers as members of Norforce participated or not. John Sanderson's essay, 'Reconciliation and the Failure of 

of military intervention as a problem-solving have broken old political and personal alliances strategy fed into Mal Brough's design for and created new ones, while attitudes to the dealing with Aboriginal social and economic coercive aspects of the intervention determine difficulties. In the discussion of 'military who will have the ear of government and who humanitarianism' that follows, Guy Rundle will not. Since its announcement, the most argues that faith in the power of military inter- vocal supporters of the emergency intervention vention as a force for good reflects forms of have lacerated the political left for creating the almost magical thinking about the nature of circumstances of poverty, drunkenness and modernity, a faith that he believes will in fact violence found in many town camps and on the entrench dependency rather than alleviate it. Aboriginal lands of the Northern Territory and

Coercive Reconciliation was the first book to the sexual violence described in the Little Chiladdress the range of issues thrown up by the dren are Sacred report. ${ }^{1}$ Noel Pearson and 'emergency intervention'. The title reflects the Marcia Langton have excoriated the left for compulsory nature of the intervention's pro- opposing the Northern Territory emergency grams and the ideology driving them. The title's intervention, while in a recent article for the reference to coercion serves to focus the essays Griffith Review Peter Sutton, non-Indigenous on a widely disputed element of the inter- anthropologist, writes that the political convention, providing a common reference point sensus of the 1970s that delivered land rights for writers from different fields, different ex- and native title was accompanied by a 'destrucpertise and differing viewpoints. The title also tive naiveté when it came to the practicalities of indicates the aspect of most concern to the life, so that progressive policy failed precisely intervention's critics. While criticism of the because it lost sight of the need to put the chilintervention covers a range of issues, questions dren first. ${ }^{2}$

concerning the need for coercion have been Because of the very great differences within central to many of them, first surfacing in re- both Aboriginal and non-Aboriginal opinion lation to the proposed compulsory sexual about the coercive nature of the intervention's health checks for children. For many critics, policies, the rhetoric of saving children has coercion strikes at the heart of people's rights as been particularly important. Saving children citizens and individuals, and it has meant that can justify anything and everything, no the protections provided by the Racial Discrim- matter how unpalatable or how coercive. ination Act have had to be suspended. As a Race One of the four sections of the book deals Discrimination Commissioner, Tom Calma's with saving children through the intervention opposition to the suspension of the Act has in some detail. Readers will find in them been unrelenting. His views on how things can much useful information; they will also get and should be done are set out in 'Tackling a sense of why opinion has become so Child Abuse and Inequality'. polarised. 
The Howard government used the Little from sexual abuse and the differences between Children are Sacred report into child sexual the intentions of the rhetoric and the direction abuse in Aboriginal communities to justify its actually taken. Her chapter should be read in determination to act. Rex Wild, who, together conjunction with Jon Altman's essay, 'In the with Pat Anderson, chaired the investigation Name of the Market', in which he sets out some leading to the Little Children are Sacred report, of the economic parameters that a focus on has written of it in his essay, 'Unforseen Circum- children leaves to one side. Altman is known stances'. He gives a very clear and concise for his view that the destruction of the comaccount of their thinking that will be useful for munity development employment projects students as well as more general readers. The (CDEP) program is unnecessary and counter level of sexual abuse documented in their productive, and his essay will help readers to report was used to justify the government's understand why. Among many others, these claim that the time for talking was over and two essays demonstrate how 'saving children' that now was the time for action, and also their neatly converts broad problems of policy, decision that compulsory programs had to government malfeasance, systematic underbe introduced. The recommendations of the funding and racial prejudice into individual Anderson and Wild report, however, together problems of moral failure.

with historical and economic aspects of Abor- The moral dimension of the intervention has iginal disadvantage, the commitment to land created a great deal of heated debate. The rights, policies of self-determination and the righteousness conferred upon those intent on value of Aboriginal cultural practices, all dis- 'saving the children' obscures from view and appeared in a cloud of policy and public moral deflects public attention away from the sadly righteousness. That shift demonstrates the ways obvious fact that children live in poverty, sufin which focusing on 'saving children' can com- fering its consequences simply because their pletely reshape the nature of public under- parents and carers do. Just fifteen or twenty standings and debate. For the government the years ago, the parents and carers who are now focus on sex with children successfully diverted the targets of the emergency intervention's new attention away from the ways in which poverty, regime of constraint and discipline were themracism and their own policies of neglect and selves the children being saved, as were their hostility have shaped the conditions now so parents before them.

decried, away from the way in which the A number of essays collected in Coercive demand for individuals to take more responsi- Reconciliation point to the consequences of bility is matched by a removal of the oppor- identifying children with an emerging future tunity to do so. while their parents are left in a past well beyond

In a short introduction to Coercive Reconcili- remediation. Such imagery offers governments ation, Melinda Hinkson sets out the parameters an easy way out. It dislocates the past from the of the government's claim to be saving children new world to emerge, it casts a mantle of 
righteousness over the most extreme of practices, and critics can be cast as condoning unfortunate 'tribal' customs or as accepting socially disastrous behaviours like drug addiction and violent assault. Small wonder, then, that a government with a poor track record in Indigenous matters might seize upon the opportunity presented by the Little Children are Sacred report to attempt to implement changes to the Northern Territory's land ownership regime that the Coalition government found so deeply confronting. Their linkage of welfare dependency and its ills with land rights has caused much fear, fury and controversy. Land ownership is therefore the second major concern of the contributors to this volume and the issues surrounding it are approached by them from a number of perspectives.

The Howard government believed that land rights in the Northern Territory had failed to deliver the prosperity and decent behaviour that it promised. Aboriginal poverty and welfare dependency were put down to the failure of policies introduced by left-wing ideologues, the bearers of romanticised views of tribal life in general and Aboriginal people in particular. Much of this rhetoric was initiated through the portals of the Centre for Independent Studies and the Bennelong Society. In his essay, The National Emergency and Indigenous Jurisdictions, Tim Rowse offers a useful evaluation of the economic rationalism of Helen Hughes of the Centre for Independent Studies whose work has been influential in providing an economic rationale for the intervention.

In Coercive Reconciliation, a number of authors (Pat Turner and Nicole Watson, for example) argue for the view that taking back the land was the underlying rationale for the intervention. Indeed, opinions concerning the role of land rights in motivating the Howard government to 'intervene' so suddenly in the Territory form one of the major fault lines along which those for and against it are ranged. The depth of feeling surrounding land rights and the very great fear created by government demands for leaseholds is perhaps most clearly visible in the fraught negotiations that led eventually to the refusal by the town campers of Alice Springs of the huge sums of money being offered to them. Given the tremendous effort and painful sacrifices put into obtaining secure title to these camps, distrust is not surprising. In 'Saying No to $\$ 60$ Million', William Tilmouth, a long-term activist in town affairs, provides a clear account of the history and the fear that led to some very disadvantaged people refusing to accept that giving up their title was their only way forward.

If attitudes to land ownership, leasing and permits have ruptured previous political alliances, so too have attitudes to alcohol, drinking patterns and proposed solutions. This issue has been at the interface of racialised community relations in the Northern Territory, with public drunkenness among Aboriginal people a constant annoyance to the nonAboriginal section of the populace. The violence associated with alcohol is an important factor in levels of injury and murder as well as in sexual assaults, burglary and other forms of criminal activity. In the intervention's programming it has been associated with pornography and other forms of drug abuse and 
targeted largely through prohibition in one form or another.

On the one hand, it is easy to understand the movement toward alcohol-free communities and the relief that prohibition brings. On the other, there are those who see prohibition as providing a temporary relief that does not deal with underlying causes. There is now a huge literature devoted to Aboriginal drinking patterns and their causes, plus a large comparative literature dealing with Indigenous peoples across the globe. Maggie Brady's essay, 'Out from the Shadow of Prohibition', offers a succinct account of why things are the way they are and a series of suggestions about how alcohol and drinking might be dealt with more effectively. In a related publication, First Taste: How Indigenous Australians Learned about Grog, she disposes of a number of the misunderstandings about Aboriginal alcohol usage found among non-Indigenous Australians and makes a particularly important observation regarding the way drinking has become a segregated activity. ${ }^{3}$ 'Research shows', she says, 'that licensed [Aboriginal] clubs do not teach moderation. ${ }^{4}$ They are clearly associated with heavy drinking. Her work indicates the difficulties with proposals for prohibition and abstinence and suggests a way forward.

Taken together, the thirty-one essays collected within this book provide a broad and detailed record of the political, economic, social and cultural landscape as it was at the moment of the intervention's inception. The prompt publication of these essays, each analysing and reflecting on aspects of the intervention, will be particularly helpful to those seeking to reach an informed understanding of the complexities bound up within it. As a volume written by people generally identified as critical of the intervention it documents an important historical moment, one that some see as the end of an era, the day in which the future arrived. As the costs and consequences of the intervention become clearer, they will be evaluated against the past as well as from the perspective of the new political landscape in Indigenous affairs now being shaped by it. This is an important book and I hope it will be read widely.

JULIE MARCUS is an anthropologist and biographer with long-standing interests in the politics of cultural differences. She has written on Muslim women's religious practices in Turkey, museums, race, land rights in central Australia, the forest wars in Tasmania and sexual differences. She is the author of The Indomitable Miss Pink. A Life in Anthropology (2002). $<j$.marcus@optusnet.com.au>

1. Rex Wild and Pat Anderson, Ampe Akelyernemane Meke Mekarle 'Little Children are Sacred': Report of the Northern Territory Board of Inquiry into the Protection of Aboriginal Children from Sexual Abuse, Northern Territory Government, Darwin, 2007

2. Peter Sutton. 'After Consensus', Griffith Review, no. 21, Spring 2008, p. 202.

3. Maggie Brady, First Taste: How Indigenous Australians Learned about Grog, Alcohol Education and Rehabilitation Foundation, Canberra, 2008.

4. Brady, bk 6, p. 22 